Кошлакова О.С., Мамин А.С.

\title{
Административные меры пресечения, применяемые органами внутренних дел в Российской Федерации
}

Белгородский государственный национальный исследовательский университет (Россия, Белгород)

doi: $10.18411 / \mathrm{j}-05-2021-177$

\section{Аннотация}

Данная статья посвящена вопросу применения мер административного пресечения в деятельности правоохранительных органов, который продолжает оставаться одним из дискуссионных и крайне проблемных. Так как меры административного пресечения имеют направленность на прекращение (прерывание) определенной ситуации или поведения, на установление личности нарушителя и обеспечение выяснения обстоятельств дела, применения к нарушителю административного взыскания, очевидно, что речь идет о довольно важном институте. Сразу же следует отметить, что проблемы в данной сфере системны, они являются многоуровневыми, что повышает внимание к институту еще более сильным образом.

Ключевые слова: меры административного пресечения, государственное принуждение.

\section{Abstract}

This article is devoted to the issue of the application of measures of administrative restraint in the activities of law enforcement agencies, which continues to be one of the most controversial and extremely problematic. Since the measures of administrative restraint are aimed at stopping (interrupting) a certain situation or behavior, at establishing the identity of the offender and ensuring the clarification of the circumstances of the case, applying an administrative penalty to the offender, it is obvious that this is a rather important institution. It should be noted right away that the problems in this area are systemic, they are multi-level, which raises attention to the institution in an even stronger way.

Key words: measures of administrative restraint, state coercion.

Проблемы применения административных мер пресечения начинаются еще на этапе существования отдельно более глобальных проблем обеспечения законности. Это центральная проблема правовой науки. Но применительно к административным мерам пресечения она изучена крайне слабо. Сложности понимания вопроса обусловлены недостаточной научной разработанности системы мер административного пресечения. В частности, сохраняется высокая степень дискуссионности в части понятия административных мер пресечения.

Антиобщественные деяния, нарушающие правовые нормы, в государственнообщественной жизни имеют своё распространение на любом этапе исторического развития общества. Поэтому, требуется существование урегулированных на законодательном уровне мер, которые могли бы применяться для прекращения противоправных деяний и привлечения в дальнейшем виновных к ответственности.

Чтобы получить однозначное представление о мерах административного пресечения, в первую очередь необходимо обратить внимание на государственное принуждение, что позволит нам затем выделить из такой структурной системы административное принуждение.

Интересным представляется тот факт, что государственное принуждение имеет семантическую связь с нормами права. Точнее, данный вид принуждения в принципе должен быть основан на праве, в противном случае, его легальность будет сомнительна. Государственное принуждение имеет конкретную целевую 
направленность - достижение задач и целей правового регулирования в государственно-политических интересах в первую очередь.

В юридической науке дискутируется вопрос о правовой природе института мер административного пресечения. Часть авторов полагает, что данный институт следует рассматривать в виде самостоятельной, независимой формы в первую очередь. Но ряд других авторов дополняет этот центральный, хотя и узкий подход. Например, можно встретить родовое причисление мер административного пресечения к видам государственного принуждения на основе действия отраслевого принципа.

Третьи склоняются к тому, что родовая принадлежность административных мер пресечения такая же, как и мер административно-процессуального обеспечения, то есть, их необходимо причислять к таким же по их правовой природе. Последняя позиция не видится верной, но все-таки, правильно будет отметить, что тесная связь двух групп мер имеет место быть. При наличии связи, речь идет о самостоятельных правовых формах принуждения - отраслевых видах принуждения, урегулированных нормами права. Данную особенность необходимо учитывать при определении понятия рассматриваемого института и при оценке различных классификационных оснований далее в исследовании.

Обращаясь к семантическому значению слова «пресекать», которое представлено в словаре В.И. Даля, следует сказать, что, хотя и значение этого слова многоаспектно, под ним следует понимать прекращение, уничтожение или остановку чего-либо. То есть, можно предположить, что меры административного пресечения имеют направленность на прекращение правонарушения.

В более глобальном смысле меры применяются для обеспечения законности в сфере публичного регулирования, то есть, это в том числе одно из средств обеспечения законности.

Так как административные меры пресечения обладают комплексным характером, все еще не разрешен вопрос о их классификации. Вероятно, он является еще более сложным, чем дискуссионности по поводу понятия. Результатом такого положения дел является отсутствие возможности вносить принципиальные изменения и дополнения в законодательство, которые были бы направлены на его совершенствование.

Одна из универсальных позиций была выражена Д.Н. Бахрахом, который считает необходимым различать такие меры, как: «меры административного пресечения, восстановления и ответственности». Автор использует как основание для классификации цель и образ действия. Хотя классификация в большей степени ориентирована на теорию, чем на правоприменительную практику, следует все же упомянуть, что в правоприменительных интересах в пределах каждой из групп могут быть названы дополнительно конкретизированные виды мер.

Современное состояние правопорядка в России продолжает вызывать определенную озабоченность, поскольку наблюдается рост числа совершения административных правонарушений. Одним из явных примеров для российских условий действительности характерно наличие временных многотысячных согласованных и несогласованных митингов, что в свою очередь вызывает возможность применения такой меры пресечения как административное задержание.

Анализ доктрины, нормативных источников и правоприменительной практики подтверждает гипотезу о том, что меры административного принуждения являются наиболее масштабной и разнообразной частью государственного принуждения. Их применение связано преимущественно с деятельностью органов исполнительной власти по предупреждению и пресечению правонарушений, с осуществлением административной юрисдикции. Тенденции и перспективы развития 
административного принуждения определяются исходя из объективной оценки потребностей использования принудительных средств в защите законных интересов личности, общества, государства. Такая потребность предопределяет выбор вида, объема и направленности использования в целях правоохраны соответствующих принудительных средств.

Как и любой подобный институт, меры административного пресечения должны иметь соответствующую систему нормативно-правового регулирования. Более того, меры административного пресечения обладают определенной спецификой, что также важно учитывать при построении такой системы.

Применение административных мер пресечения урегулировано на международном уровне и национальном. Конституция РФ закрепила основные права и свободы человека и гражданина, наложила запрет на применение пыток. На этой основе разработаны и развиты положения об административных мерах пресечения и их применения в федеральных законах . Одним из таких является Федеральный закон от 07 февраля 2011 г. № 3-Ф3 «О полиции».

На международном уровне существует ряд документов, так или иначе связанных с административными мерами пресечения. Но можно выделить главный документ, тем более что именно он ратифицирован в России. Речь идет о Европейской конвенции о защите прав человека и основных свобод. Например, в ст. 3 Конвенции налагается запрет на применение пыток: «Никто не должен подвергаться ни пыткам, ни бесчеловечному или унижающему достоинство обращению или наказанию». В ст. 5 Конвенции провозглашено право на свободу и личную неприкосновенность, что означает, что никто не может быть лишен свободы иначе как в определенных случаях и в порядке, определенном законом. Это та основа, которая в том числе была положена в построение национального уровня нормативно-правового регулирования применения административных мер пресечения.

Таким образом, меры административного пресечения имеют свою главную цель - обеспечение общественного порядка в государстве, так без такого механизма сохранение общественной безопасности будет невозможным и государство не сможет в должной степени обеспечивать безопасность своих граждан. Таким образом, применение мер административного пресечения должно осуществляться ОВД РФ в объеме и в рамках, достаточных для достижения правовосстановительных целей, установленных действующим законодательством.

$$
* * *
$$

1. Конституция Российской Федерации (принята всенародным голосованием 12.12.1993) (с учетом поправок, внесенных Законами РФ о поправках к Конституции РФ от 30.12.2008 N 6-ФКЗ, от 30.12.2008 N 7-ФКЗ, от 05.02.2014 N 2-ФКЗ, от 01.07.2020 N 11-ФКЗ) // Собрание законодательства РФ, 01.07.2020, N 31.

2. Конвенция о защите прав человека и основных свобод 1950 г. // Собрание законодательства Российской Федерации. 2001. № 2.

3. Федеральный закон «О полиции» от 07 февраля 2011 г. № 3-Ф3 (ред. от 24.02.2021) // Собрание законодательства Российской Федерации. - 2011. - № 7.

4. Административное право / Под ред. Л. Л. Попова. - Москва : Юристъ, 2005. - 703 с.

5. Бахрах, Д. Н. Административное право : учебник для вузов / Д. Н. Бахрах, Б. В. Россинйский, Ю. Н. Старилов. - Москва : Норма, 2007. - 816 с.

6. Ильясов, М. 3. Система мер административного принуждения: теоретические подходы к классификации / М. 3. Ильясов // Вестник экономической безопасности. - 2010. - № 2. - 247 с.

7. Ковшевацкий, В. И. Правовая природа и назначение специальных мер административного пресечения / В. И. Ковшевацкий, С. П. Стащенко // Вестник экономической безопасности. - 2017. - № 6. -194 c. 